\title{
Effect of Tempe Drinks on Muscle Recovery (Malondialdehyde) and Sub-Maximum Activity on Sparta DK Percut Sei Tuan Football Players in Deli Serdang Regency, North Sumatra Province
}

\author{
Winara $^{1}$, Oktia Woro Kasmini Handayani ${ }^{2, *}$, Sulaiman $^{2}$, Rumini $^{2}$ \\ ${ }^{1}$ Sports Education Study Program (S3), Postgraduate Semarang State University, Semarang, Indonesia \\ ${ }^{2}$ Public Healthy Program, Sports Education Study Program, Postgraduate Semarang State University, Semarang, Indonesia
}

Received September 22, 2020; Revised December 24, 2020; Accepted January 6, 2021

\section{Cite This Paper in the following Citation Styles}

(a): [1] Winara, Oktia Woro Kasmini Handayani, Sulaiman, Rumini, "Effect of Tempe Drinks on Muscle Recovery (Malondialdehyde) and Sub-Maximum Activity on Sparta DK Percut Sei Tuan Football Players in Deli Serdang Regency, North Sumatra Province," International Journal of Human Movement and Sports Sciences, Vol. 9, No. 1, pp. 130-134, 2021. DOI: 10.13189/saj.2021.090118.

(b): Winara, Oktia Woro Kasmini Handayani, Sulaiman, Rumini (2021). Effect of Tempe Drinks on Muscle Recovery (Malondialdehyde) and Sub-Maximum Activity on Sparta DK Percut Sei Tuan Football Players in Deli Serdang Regency, North Sumatra Province. International Journal of Human Movement and Sports Sciences, 9(1), 130-134. DOI: 10.13189/saj.2021.090118.

Copyright $\mathrm{C} 2021$ by authors, all rights reserved. Authors agree that this article remains permanently open access under the terms of the Creative Commons Attribution License 4.0 International License

\begin{abstract}
The purpose of this study was to see: The effect of submaximal physical activity to increase MDA levels in the blood of soccer players given submaximal physical activity. The effect of giving tempe drinks for 2 weeks on changes in MDA (malondialdehyde) levels after getting submaximal physical activity in the sample. Providing tempe drinks with MDA levels in the players' blood, the sample consists of 15 players who get high sub-maximum physical activity (pulse) and 15 players who get sub-maximum physical activity (pulses). The instruments used to collect data are: physical activity running 2400 meter pulse measurement and MDA test (malondealdehyde). There was a significant effect on muscle recovery that was given tempe drinks, namely offering tempe drinks. The MDA (malondialdehyde) muscle recovery rate was very fast compared to samples that were not given tempe drinks (the average value of the players who were given tempe drinks was around $\mathrm{F}=42$ ). It can be seen from the MDA blood while without offering the tempe drink $F=47$. The data will show that muscle recovery is faster if you are given tempe drinks defeatingly because in the tempe content there is a lot of protein so that muscle recovery is faster.
\end{abstract}

Keywords Provision of Tempe Drinks, Muscle Recovery, Sub-Maximum Activity

\section{Introduction}

Health is the basic capital for preserving the quality of human resources. Health is meant to be healthy physically, mentally and socially, which is expected to result in the quality of human resources as a whole (KDI Keolahragaan, 2000). One way to achieve health is by exercising, so that exercise is necessary for all levels of society.

Physical activity is a life activity that must be developed in the hope that it can provide added value in the form of increasing quality, welfare and human dignity. Physical activity can influence various aspects of life such as psychological, social, economic, cultural, political and biological functions. Regarding biological functions, physical activity is a modulator with a broad spectrum of effects and can occur at the level of function. The effect of physical activity on biological functions can be in the form of positive effects, namely repair, while negative 
effects are inhibiting or damaging.

This is supported by previous research. Participants were 74 football players of all the first division clubs in Karbala, Iraq, aged between 18-22 years old. Depression, anxiety and stress were measured at three different time points (resting time, before the training, before the competition), while salivary IgA, pulse rate, and oxygen saturation measurement were measured through five different time points (resting time, before the training, after the training, before the competition, after the competition). It can be concluded that the combination of psychological distress and physiological markers can provide accurate measurements of stress. Research by Farah Layth Naji (2020) Psychological Distress and Physiological Markers: Differences Comparisonin First Division Football Players

Training is an important thing that must be done by an athlete before participating in a competition. One of them is strength training such as lifting weights, and this strength training will trigger muscle damage which is characterized by an increase in serum creatine kinase levels, muscle pain and decreased muscle strength. The results of research conducted by Udani and Singh (2009) revealed that there was an increase in muscle damage and pain after doing strength training with squats. Research by Cooke (2010) shows a significant increase in damage.

In previous studies increased physical exercise can have a very significant effect on the body. The graded incremental test was executed on a treadmill adjusted with a gradient of $1.5 \%$. All tests started with an initial workload of $6 \mathrm{~km} / \mathrm{h}$ for 3 minutes and incremental $2 \mathrm{~km} / \mathrm{h}$ increases every 3 minutes until subjective exhaustion was reached with a minimum of five steps. Between steps, a 30 second break took place for capillary blood extraction. Subsequent to the last incremental step, another step of 3 minutes with the previous initial workload of $6 \mathrm{~km} / \mathrm{h}$ took place Research by Stefan Endler et al (2017) The PerPot Simulated Anaerobic Threshold - A Comparison to Typical Lactate-based Thresholds.

One of the causes of changes in muscle condition in sports is the intensity of physical activity or the intensity of exercise. There are many ways to determine the intensity of physical activity, for example from the percentage of maximum speed, percentage of maximum strength, percentage of maximum heart rate or based on the predominant energy used during physical activity. A lot of at least the body's use of oxygen is closely related to the formation of free radicals which result in poor muscle condition after physical activity.

A case study conducted by a researcher who has been a former first division coach for 3 years in a soccer team in North Sumatra, precisely in Deli Serdang Regency, found things that hinder the player's performance and health. This is in the form of a very busy match schedule between only 2 days after the match, plus the official competition for the Indonesian Football Association (PSSI) which is held regularly throughout Indonesia with a maximum age category of 19 years. Due to the tight match schedule making it difficult for players to recover their specific muscles, in addition, if the player's protein consumption is insufficient, this can cause symptoms of damage to the muscles that are continuously used but the nutritional content is insufficient.

The researcher made some special observations on the football team in Deli Serdang, namely the Sparta Dk and Garbin FC teams, this team is included in the Deli Serdang football first division, the first division is the 3rd caste competition organized by PSSI. The observations by researchers on this team were in the form of: 1 . Training Program 2. Competition 3. Nutrition intake of players. In the training program, the researchers did not find many significant problems, maybe because the standard first division trainers must be licensed so that the training program is quite good. But on the other hand, the competition is too close to the pause period for the game to result in players having to recover to face the next match. This results in the physicality of the players in the category not fully recovered because the gap is only 1 day. In the nutritional intake of players in a special interview with the team coach and several players, there was no menu given to the players to face the competition, either in training.

Games that are too dense plus insufficient nutritional intake for players can cause muscle damage to players due to lack of protein and vitamin intake in athletes, so players need high protein intake that is also natural for their bodies.

In red guava, there is a very large vitamin $\mathrm{C}$ content in 100 grams of red guava, there are $889 \mathrm{mg}$ (Djoko 2010). Vitamin $C$ is a very strong antioxidant and can prevent the oxidation process in food and in the human body system (Tejasari, 2005). Vitamin $\mathrm{C}$ has many functions in the body, as a coenzyme or cofactor. Ascorbic acid is a material that has strong radiation ability and acts as an antioxidant in hydroxyl reactions (Almatsier, S. 2009).

In addition to red guava which can reduce free radicals so that it can accelerate the muscle recovery period in athletes. Besides that, the content in tempe can also accelerate recovery because the content of tempeh is high in protein, the protein in tempeh is greater than that in beef and soybeans.

The purpose of this study was to see the effect of tempe drinks on muscle recovery in a soccer team that was previously given 2400 meter submaximal exercise so that the muscles in the sample body experienced fatigue and then given tempeh drinks as muscle recovery.

\section{Materials and Methods}

This study used an experimental method in a $2 \times 2$ factorial design. The sampling technique was perpousive sampling and obtained a sample of 30 people from a total population of 50 people. The data analysis technique used 
a two-way ANOVA test with SPSS 20.0 program and a significance level of 5\%, followed by Tukey's test.

19991493This study used an experimental method with a $2 \times 2$ factorial design, two variables were manipulated simultaneously to investigate the effect of each level on the dependent variable and the effects caused by the interaction between several variables.

MDA measurement in blood plasma is because most of the MDA in blood is found in plasma, apart from serum and tissue (Konig \& Berg, 2002). The blood plasma obtained is then used to check MDA levels. Method of Measuring Levels of MDA

The MDA measurement method used is the TBA (Thiobarbituric Acid) method. According to Yagi (1994), the TBA method has a high sensitivity value to free radicals and is easily applied to samples in various oxidation stages. TBA will react with carboxylate groups from MDA through the addition of nucleophilics to form MDA-TBA complexes in an acidic atmosphere and produce colored products so that they can be quantified by spectrophotometry (Yagi, 1994).

Table 1. 2 x 2 Factorial design

\begin{tabular}{|c|c|c|}
\hline \multirow{2}{*}{$\begin{array}{c}\text { The pulse } \\
\text { sub-maximum (B) }\end{array}$} & \multicolumn{2}{|c|}{ Tempe Drink } \\
\cline { 2 - 3 } & No Give (A $\left.\mathrm{A}_{\mathbf{1}}\right)$ & $\begin{array}{c}\text { GiveTempe } \\
\text { Drink(A) }\end{array}$ \\
\hline & $\mathrm{A}_{1} \mathrm{~B}_{1}$ & $\mathrm{~A}_{2} \mathrm{~B}_{1}$ \\
\hline & $\mathrm{A}_{1} \mathrm{~B}_{2}$ & $\mathrm{~A}_{2} \mathrm{~B}_{2}$ \\
\hline
\end{tabular}

Information:

$\mathrm{A}_{1}=$ Without Giving Tempe Drink

$\mathrm{A}_{2}=$ Giving Tempe Drink

$\mathrm{B}_{1}=$ High pulse

$\mathrm{B}_{2}=$ Low pulse

$\mathrm{A}_{1} \mathrm{~B}_{1}=$ The group that was not given tempeh drinks in the sample who received sub-maximal physical exercise with high pulse results.

$\mathrm{A}_{2} \mathrm{~B}_{1}=$ The group that was given Tempe Drinks was the sample who received sub-maximal physical exercise with high pulse results.

\section{Results and Discussion}

\subsection{Comparison of the effect of giving Tempe Drinks on Muscle Recovery (Malondialdehyde) in DK Sparta Players}

To test the hypothesis which states that the difference in the effect of Tempeh Drinks on Muscle Recovery (malondialdehyde) in Sparta DK Players, two Way analysis of variance was used. The following results were obtained:
Table 2. Analysis of Influence Variance between Giving Tempe Drinks on Levels of MDA (Malondialdehyde) in Sparta Dk Players

\begin{tabular}{|c|c|c|}
\hline Source of Variation & Add Red Guava Juice & Total \\
\hline $\mathrm{dk}$ & 1 & 12 \\
\hline $\mathrm{JK}$ & 25.5 & 7.6 \\
\hline $\mathrm{JKT}$ & 25.5 & 0.6 \\
\hline $\mathrm{Fc}$ & \multicolumn{2}{|c|}{42} \\
\hline $\mathrm{Ft}$ & 47 \\
\hline $\mathrm{Sig}$ & \multicolumn{2}{|c|}{0.00} \\
\hline $\mathrm{Exp}$ & \multicolumn{2}{|c|}{ Significance } \\
\hline
\end{tabular}

Based on the results of the analysis of the difference in the effect of giving tempeh drinks on muscle recovery (Malondialdehyde) in DK Sparta players, the calculated F value is 42 and the $F$ table is 4.747 with a $\mathrm{p}$ value or a significance level of 0.000 , because the value of $f$ count (42) $>\mathrm{F}$ table (47) and a significance level of $0.000<0.05$, which means that Ha which says "there is an effect of muscle recovery on the provision of tempeh drinks

The results of the average MDA (Malondialdehyde) levels in Sparta DK athletes with the provision of teme drink can be seen in the following table: Table 3 : The results of the average levels of MDA (Malondialdehyde) on athlete Sparta DK by administering not give tempe drink and give tempe drink

Table 3. MDA measurement results given tempeh drink

\begin{tabular}{|c|c|c|}
\hline \multicolumn{2}{|c|}{ Dependent Variable : Result of MDA Test } & \\
\hline Administering Tempe Drink & No Give & GiveTempe Drink \\
\hline Mean & 47 & 42 \\
\hline Std.Error & .281 & .281 \\
\hline
\end{tabular}

Based on the table above, it is known that the average result of muscle recovery which can be seen from the MDA (Malondialdehyde) levels in Sparta DK players by giving Tempe Drinks an average result of 42 while the average MDA (Malondialdehyde) levels in Sparta DK players are not given drinks. tempe, the average yield is 47 , so the difference in the average MDA (Malondialdehyde) muscle healing rate between giving tempeh drinks and without giving tempeh drinks is 5 . there is a decrease of 5 out of 47 muscle conditions that are given submaximal training without giving tempe give the tempeh drink to 42

The results of giving 2400meter training to Sparta $\mathrm{dk}$ players have 47 for the level of muscle fatigue as seen from the MDA results on the players' blood.

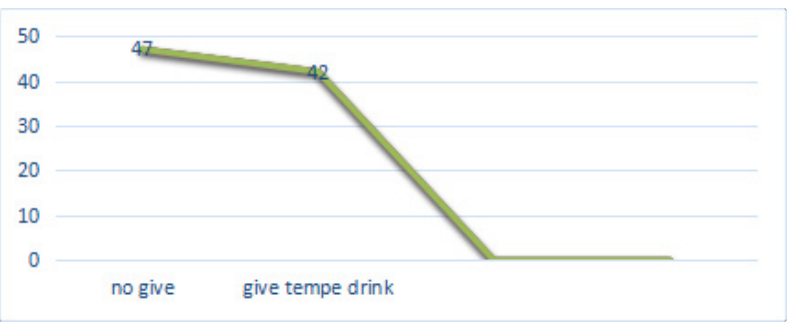

Figure 1. Graph of decrease after giving tempeh drink 
The data on the results of giving tempeh drinks to Sparta dk players who were given 2400 meters of physical activity decreased 42 of the 47 this had a significant impact on the content of tempeh drinks on muscle recovery during high activity.

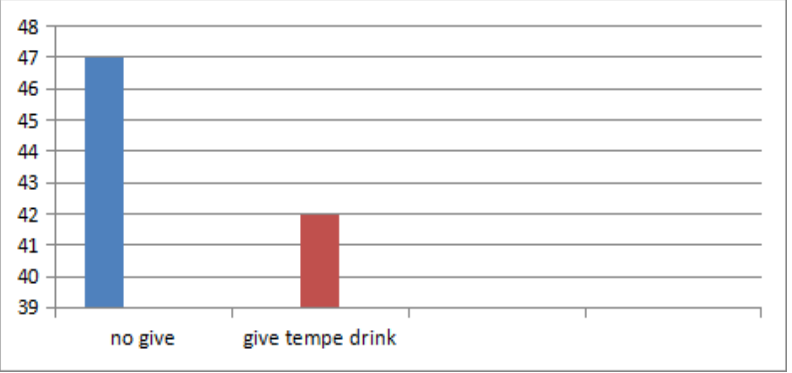

Figure 2. Giving tempeh drinks to physical activity

The figure above shows a very significant comparison between giving tempeh drinks and without giving tempe drinks. The figure shows a 5 point ratio for the reduction when given tempeh drinks during high activity

\section{Conclusions}

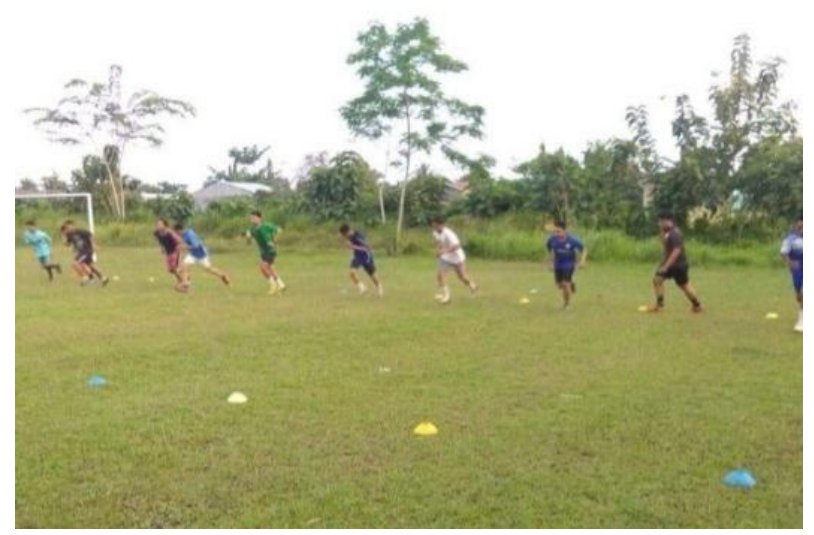

Figure 3. Provision of $2400 \mathrm{~m}$ submaximum activity to the player

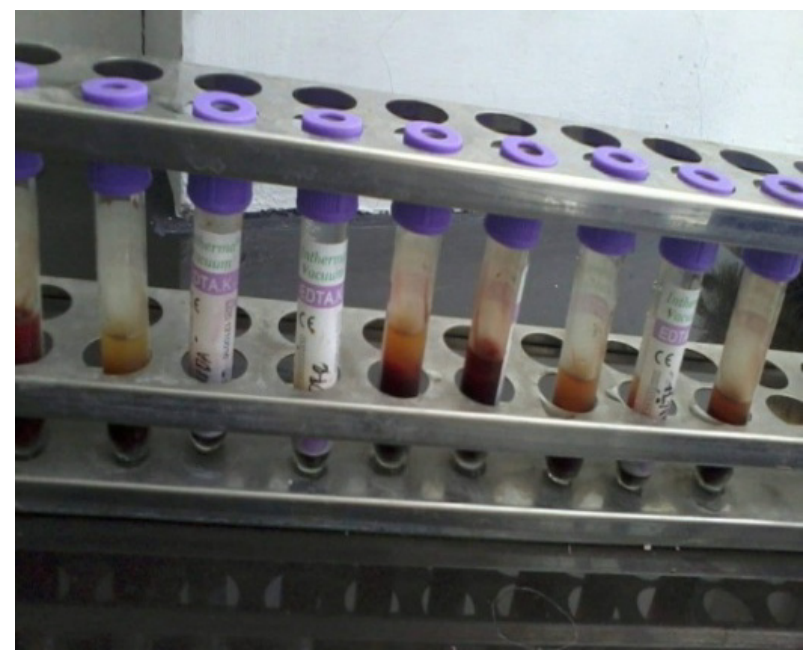

Figure 4. Blood sampling (MDA) of players who have been given submaximal physical activity and tempe drinks
The picture above is the initial process of providing submaximal physical activity in the form of running 2400 meters, then giving tempeh drinks and then taking the players' blood (MDA) to see a decrease in high oxidative stress which makes young players tired because the muscles in the players are not enough for muscle intake for recovery

This study is to look at muscle recovery in the $\mathrm{dk}$ Sparta team soccer player. Given quite tiring training, namely submaximal in the form of running 2400 meters which produces high and low pulse, each sample will be divided into 2 groups, in which the first group is given tempeh drink and the second group is not given tempe drink, which aims to see how fast the player's muscle recovery is. There is high protein in tempeh so it can speed up muscle recovery. The ingredients for making tempe used are tempe pollen that have been produced by the company so that the nutritional value of the tempe content can be measured.

This research method uses experimental measurements through the blood of the Sparta dk soccer player. The pre-test and post-test of the players perform submaximal physical activity to run 2400 meters after that, the players will take blood to see how fast the recovery is through the content of MDA (malondehyaldehide) in the players blood. From this conclusion, there is a very significant effect on the provision of tempeh drinks given by the Sparta dk football players who are given submaximal training in the form of running 2400 meters with high and low pulses there is an acceleration of recovery with a value of 42 to players who are given tempeh drinks compared by not giving tempeh drinks with a value of 47 . This is because the protein content in tempeh drinks makes muscles work better when doing high activities so that this tempeh drink is very well used for athletes to meet nutritional standards for themselves. This shows a change in conditions when players experience muscle fatigue. Intake of tempeh drinks really helps to care for muscles that do high activity.

\section{REFERENCES}

[1] Arief P.S, “Agribisnsis Guava (Jambu Batu)", CV. Pustaka Grafika, Bandung, 2010

[2] Almatsier. S, "Prinsip Dasar Ilmu Gizi”, edition 6, Gramedia Pustaka Utama, Jakarta, 2006

[3] Arsana, I Nyoman, "Ekstrak Kulit Buah Manggis dan Pelatihan Fisik Menurunkan Stress Oksidatif Pada Tikus Wistar Selama Aktivitas Fisik Maksimal”, Udayana University, Bali, 2014

[4] Bagchi K., \& Puri S, "Free Radicals and Antioxidants in Health and Disease", Eastern Mediterranean Health Journal, vol 4, no. 2, pp 60-350, 1998

[5] Bagiada, N.A, "Proses Penuaan dan Penanggulangannya", 
Medical School, Udayana University, Denpasar, 2001

[6] Catala A, "Lipid Peroxidation", Int. J Biochem Cell Bio 1., vol 38, no 1482-95, 2006

[7] Chevion S, Moran DS, Heled Y, Shani Y, Regev G, Abbou B, Berenshtein E, Stadtman E R, Epstein Y, "Plasma Antioxidant Status and Cell Injury After Severe Physical Exercise", Proc Natl Acad Sci U S A, 100, 5119-23. 2003

[8] Clarkson PM, Thompson HS, "Antioxidants:What Role do They Play in Physical Activity and Health?, Am J Clin Nutr, vol 72, pp 637S-46S, 2000

[9] Davies K, "Oxidative Stress: The Paradox of Aerobic Life". Bioche Soc Symp. vol 61, pp 1-31. PIMD 8660387. 1995

[10] Djoko P I, "Panduan Gizi Lengkap Keluarga dan Olahragawan”, CV. Andi Offset, Yogyakarta, 2007

[11] Farah Layth Naji, Tengku Fadilah Tengku Kamalden, Saidon Amri, "Psychological Distress and Physiological Markers: Differences Comparison in First Division Football Players," International Journal of Human Movement and
Sports Sciences, Vol. 8, No. 1, pp. 43 - 49, 2020. DOI: 10.13189/saj.2020.080106.

[12] Griwijoyo., "Ilmu Kesehatan Olahraga", Indonesia Education University, Bandung, 2007

[13] Komisi Disiplin Ilmu Keolahragaan, "Ilmu Keolahragaan dan Rencana Pengembangannya”, Depdiknas, Jakarta, 2002

[14] Konig D \& Berg A, "Exercise and Oxidative Stress: Is there a Need for Additional Antioxidant" Osterreichisches J Fur Sport medizin, vol 3, pp 6-15, 2002

[15] Tejasari.. Nilai-Nilai Gizi Pangan. Graha ilmu. Jakarta, 2005

[16] Stefan Endler, Sabine Hoffmann , Björn Sterzing, Perikles Simon, Mark Pfeiffer, "The PerPot Simulated Anaerobic Threshold - A Comparison to Typical Lactate-based Thresholds," International Journal of Human Movement and Sports Sciences, Vol. 5, No. 1, pp. 9 - 15, 2017. DOI: 10.13189/saj.2017.050102.

[17] Yagi, K. "Free Radical in Diagnostic Medicine", Plenum Pr, New York, 1994 